\title{
A Brief History of Bullying in Nursing: Battles and bullies
}

\author{
Dr David Stanley* \\ Faculty of Health Sciences, Australian Catholic University, Canberra, Australia
}

Submission: August 30, 2019; Published: September 09, 2019

*Corresponding author: David Stanley, Faculty of Health Sciences, Australian Catholic University, Antill Street Watson, Canberra ACT Australia, Australia

\section{Commentary}

I am sure all nurses have war stories about nurses who have bullied us, or of colleagues who have been bullied. One study Lee et al. [1] put the rate of bullying amongst nursing at $98 \%$. While this is shocking...I am sure we have all thought; Why is this so? Graveyard Alive; A Zombie Nurse in Love; is a wonderful Canadian film that is based on a story about a shy nurse who is bullied and belittled and who gets her revenge when, as a Zombie she is able to manipulate, dominate and subsequently bully (and eat) her previous antagonists. Funny and bloody and sadly close to the mark in some places, however zombification is not a strategy I recommend for dealing with bullies. The lesson from this film is that only by becoming a bully can we overcome bullies. And herein lies the issue embedded in the history of nursing. My thesis is that nursing started with conflict and bullying behaviour and that this tone has set the template for our profession from the very start and it remains so to this day.

Derbyshire and Watson's (2019) article "Nursing's Future? Eat Young. Spit out. Repeat. Endlessly." Links bullying back 40 odd years when Meissner (1986) identified this theme and asked the question, "Are we eating out young?" Although, I wonder if the link to our past is more extensive? Can we look back further and see something in our professional origins that explains how the template was set for bullying and why I fear we may have been locked into a cycle of bullying within the nursing profession? The aim of this paper is to highlight some key 'bullying' events from nursing's past and see if there is something in the development of nursing that has set the tone for our capacity to bully and belittle our colleagues. Indeed, is there something in the 'nature' of nursing that precipitates a tendency to be unkind toward or to bully each other? In exploring this thesis, I have focused on specific episodes in nursing's early development during the Crimean War, American Civil War and First World War. Although much has happened since these times, have events at these pivotal times in our early history been able to create a template for how nurses and nursing has progressed?

\section{Conflict at out Heart}

Conflict has been at the heart of our profession's development from the start, but I do not mean that nursing has developed in conflict zones, although we have been present there for a long time. However, even while the conflict, wars and battles stormed about the hospitals and tents where nurses worked, nurses have been in conflict with each other and this I suggest has set the tone for how nursing and nurses have related to each other since the start of the professional era.

\section{The Crimean War}

In the Crimean War conflict in nursing revolved about nurses who were paid and those who were unpaid. Payed nurses tended to be lower class and seen by the 'ladies' who managed them as needing their moral guidance. Paid nurses were not well regarded in general and Florence Nightingale said that less than half were able to contribute well. The volunteer and unpaid 'ladies' were placed in positions of authority over the paid nurses. There was greater status placed on the unpaid nurses who were seen to be 'there' with greater moral authority. There were also class differences reflected in the class system of Victorian Britain. Class differences very much impacted upon the relationships between middle class 'lady' nurses and the lower-class paid nurses [2]. All wore the same uniform, but the paid nurses, although promised equality of status by Sidney Herbert before their departure were soon, used as domestic servants by the lady's and were regarded as immoral, drunkards and in need of strict supervision.

As well, there was conflict between religious and nonreligiously motivated nurses. The paid nurses were there for the wages (paid twice that of nurses back in England), the nuns were there for God and the volunteers to likewise do God's good work. Saving souls and healing became intertwined and who managed the nurses was also determined to a large extent by what motivated them. Generally, nuns managed other nuns, and various ladies managed the paid nurses as superintendents. Nuns 
of different faiths also fought over access to the souls of the men. Throughout the Crimean War, nurses fought over petty jealousies, leadership, access to resources and power, financial control, access to the soldier's souls and control of perceptions back in the UK [3]. Letters and public information in the press carried great weight and Florence Nightingale controlled much of this, but not all and battles between her, other ladies, the nuns, the medical officers, the war department and the various aids and advisors to the Royal family and wider media were all fought in destructive ways. Nursing grew from and thrived upon conflict, bitterness, jealousy and backstabbing, with one of the most bitter battles being fought between Florence Nightingale and Mary Stanley [4]; [5] supporting a poor platform for the profession of nursing to be founded on.

\section{The American Civil War}

Nurses in the American Civil War also fought with each other over similar issues. There was also conflicts between paid and unpaid nurses as un-paid volunteers saw themselves as being more superior and again paid nurses were lower class and more mercenary. Middle class nurses resented the suggestion that their motivation was finical rewards; as Morris Bradly (who called herself Amy) showed when a surgeon asked whether she was a paid nurse. "To think that I poor Amy Bradley would come out here to work for money and that the paltry sum of 12 dollars a month and rations. Thank God I had a higher motive than a high living and a big salary' [6]. As well, Clara Barton (probable the most famous nurse in the Civil War) said, "My own living has been such as our Government provides for its troops: hard crackers, often mouldy and wormy salt meat and water. And from no person, or persons or society or commission or bureau or any other conceivable source have I ever received one dollar of salary or reward...I derived to labor without reward, and I have done it." She went on to criticize the institutionalization of hospital work and the monetary recognition of that work. These beginnings may have set the tone for nursing to have been a low paying profession. Division also occurs between nurses who worked in the West or Eastern theatres of the war, with nurses in the West having less resources and limited access to charitable organizations. In the East they were closer to the seat of political and military power and so had greater access to resources.

Race also divided the nurses in the north where white nurses felt resentment towards African American nurses who were sometimes freed slaves, sometimes paid and sometimes volunteers. Racism was more common in the North were race was still being adjusted to as an issue. In the South, racism was not an issue, African Americans new their place. Here, the main divide was class. White people were less worried about the balance of race and simply ignored it as a 'settled' issue. Class differences in the south meant that wealthy women saw their contribution as more in keeping with their class, so they did little manual work (laundry or cooking). Only slaves (who's wage if they earnt one went to their master) or poor lower-class white women, did manual work. Again, nursing was in conflict with itself. The medical profession added to the insecurities early nurses felt as they badgered and hindered nurses by limiting supplies and resources, and ensuring pay was infrequent. Nurses could do little to address these issues, so as with other oppressed groups, they fought each other.

\section{The First World War}

In this conflict nurses again faced similar internal conflicts. Friction between paid and unpaid nurses continued, however, this time the paid nurses had the upper hand. They were critical of the volunteers and often treated them with contempt. Vera Brittan's war dairy is replete with stories of conflict between nurses [7]; [8]. She said, "I came home to-night wearier and more footsore than I have been since I started nursing. This is all the fault of one charming Sister who this morning had me on the run \& besides my ordinary work made me follow her around cutting toe-nails and washing their hands and feet." Months later she said, "The way they treat us like children here and make mysteries of trifles is too ridiculous for words." Friction also arose with resentment between long serving staff nurses and newly arrived 'Sisters' who were paid more but had not served as long or had less experience.

Conflict occurred between nurses at the 'front' near the battles, who had greater kudos and greater reputation/authority. Working at home (in rehabilitation) was not 'real' war nursing and nurses were seen to have more lustre if in the thick of the fight. There was also resentment by the nurses at home toward the military nurses for going 'over there' and in Australia, there was some resentment of nurses trained in different states. As Kitty McNaughton (while travelling to the First World War conflict) describing nurses from another state saying, "Some of these nurses need to be put overboard the way they nurse." She was from Victoria and had a low opinion of nurses from other states. She added, "I hope I never fall into their hands" [9]. Myths are like mist. They hide and confound the truth. However, it is only by honestly and diligently searching in our past that we can avoid (and hopefully) correct the mistakes of history. It is difference unaccepted and conflict unresolved that corrupts relationships and builds contempt. The thesis here is that early nurses were oppressed, by a dominant patriarchal system, resentful Army Medical staff and by internal fights over power, pay, influence and resources. Oppression remains at out heart, even today, or why else would we still, as Derbyshire and Watson (2019) suggests, eat our young?

Failing to address the curse of bullying will limit the magnificent contribution nurses can make to the health service and it will keep potential nurses from joining or staying in the profession and it will injure and belittle countless good people who want to make a difference and care for others [10]. However, if we go on fighting each other and walking down the bully/ oppressor/victim pathway (established more than a century 
and a half ago) we will go on repeating the mistakes of the past, endlessly. History, I suggest, should be a warning, not a template.

\section{References}

1. Lee YJ, Bernstein K, Lee M \& Nokes KM (2014) Bullying in the Nursing workplace: applying evidence using a conceptual framework. Nursing Economics 32(5): 255-267.

2. Summers A (1983) Pride and Prejudice: Ladies and Nurses in the Crimean War. History Workshop Journal (16): 33-56.

3. Stanley D (2017) (Ed). Clinical Leadership in Nursing and Healthcare: Values into action. Oxford. Wiley Blackwell.

4. Baylen JO (1974) The Florence Nightingale / Mary Stanley Controversy: Some Unpublished Letters. Medical History 18: 186-193.

5. Bostridge M (2008) Florence Nightingale: The woman and her legend. Viking Press, London.
6. Schultz JE (2004) Women at The Front. Hospital Workers in Civil War America. University of North Carolina Press, Chapel Hill and London.

7. Brittain V (1980) Testament of Youth (7th Ed). Fontana Paperbacks, Glasgow, Scotland.

8. Bishop A, Smart T (1982) (Eds). Chronicle of Youth. Fontana Paperbacks, Glasgow, Scotland.

9. Butler J (2013) Kitty's War University of Queensland Press, Queensland, Australia.

10. Mikaelian B \& Stanley D (2016) Incivility in Nursing: From Roots to Repair. Journal of Nursing Management 24: 962-969.

\section{Your next submission with Juniper Publishers will reach you the below assets}

- Quality Editorial service

- Swift Peer Review

- Reprints availability

- E-prints Service

- Manuscript Podcast for convenient understanding

- Global attainment for your research

- Manuscript accessibility in different formats

( Pdf, E-pub, Full Text, Audio)

- Unceasing customer service

Track the below URL for one-step submission https://juniperpublishers.com/online-submission.php 